\title{
Attitude of Livestock Farmers towards the ICT based Livestock Extension Services in Jaipur District of Rajasthan, India
}

\author{
Sunil Rajoria ${ }^{*}$, Sanjay Kumar Rewani ${ }^{2}$, Virendra Singh ${ }^{2}$, Manisha Singodia $^{2}$, \\ Brijesh Nanda $^{3}$ and Harshita Bhumra ${ }^{4}$
}

\author{
${ }^{1}$ Veterinary University Training and Research Center, Dungarpur- 403001, India \\ ${ }^{2}$ Department of Veterinary and Animal Husbandry Extension Education, Post Graduate \\ Institute of Veterinary Education and Research, Jaipur- 302031, India \\ ${ }^{3}$ Department of Livestock Product Management, Apollo College of Veterinary Medicine, \\ Jaipur-302031, India \\ ${ }^{4}$ Department of Veterinary and Animal Husbandry Extension Education, College of \\ Veterinary and Animal Science, Navania, Vallabhnagar, Udaipur-313601, India
}

\section{*Corresponding author}

\section{A B S T R A C T}

\begin{tabular}{|l|}
\hline K e y w or d s \\
Attitude, ICTs, \\
Livestock \\
farmers
\end{tabular}

An exploratory study was conducted to measure attitude of livestock farmers towards Information and Communication Technology (ICTs) used in extension services as a source of information livery in Rajasthan, India. A total of 120 respondents were randomly selected for the study. Data were collected through structured interview schedule and analysed through different statistical tools. The study revealed that majority of livestock farmers had favourable attitude $(73.33 \%)$ towards dissemination of information through different ICT tools in livestock sector followed by 15.83 per cent with more favourable attitude and 10.83 per cent with less favourable attitude. Age, family size, land holding, herd size, extension contact and social participation had positive and non-significant relationship with attitude of livestock farmers towards ICTs, while experience in livestock farming had negative and non-significant relationship. Education, mass media exposure and annual gross income had positive and significant relationship with attitude of livestock farmers towards ICTs.

\section{Introduction}

Primarily, India is an agrarian country and agriculture is the backbone of Indian economy. Livestock sector is an integral part of the agricultural system in India and contributes significantly to the GDP. It ensures food and nutritional security on one hand and provides income and employment opportunities on the other hand (Ravikumar and Mahesh, 2006; Borah and Halim, 2014).

India's public extension system accounts for only a small percentage of farmer's information sources. Farmer to farmer informal exchanges remains the main channel for accessing information and new technologies in India (Anonymous, 2005). 
Traditionally, the potential sources of information for farmers on various aspects of production, marketing and finance include media, government extension services, consultants and farm service firms, traders, input dealers, other farmers and relatives (Mittal and Kumar, 2000; NSSO, 2005 and Saravanan, 2011) that has became very tedious method in service delivery system.

Recent developments in ICT offer a great opportunity to facilitate the flow of information and technology services delivery especially to the farmers (Maningas, 2006).Use of Information and Communication Technology (ICT) tools has potential to change the economy of livestock, agriculture and rural artisans in India (Sasidhar and Sharma, 2006). The delivery of information and knowledge to the farmers on the right time and in right way leads to more productivity and more profitability. Thus, the information delivery system should include technology to impart the information and knowledge to the livestock farmers. So, these ICT tools are the demand of hour.

ICT refers to all information and communication systems and technologies including not only the digital formats such as the internet or the World Wide Web (WWW), but also interfaces with radio, cable and wireless television, video, cellular phones and print media (Hazelman and Flor, 2004). ICTs are integrated with different devices such as computer, internet, mobile phones, television and radio. According to Elijah and Ogunlade (2006), there are three categories of ICTs viz. advance ICTs (computer, internet and mobile phone), conventional ICTs (radio, TV, land line telephone and telegraph) and really old ICTs (newspaper, books and libraries). Some of the modern ICT tools are Geographic Information Systems (GIS), Global Positioning System (GPS), Database Management System (DMS), Computer Aided
Design (CAD), Artificial Intelligence (AI), Information System and Learning Management System which are being used effectively and efficiently in various sectors.

Adequate access to knowledge and information is the least expensive input to amend livestock sector. ICT tools can be used to impart information and knowledge and that in turn will lead to motivation, mobilization and action to do something better in livestock sector. ICTs have played very effective role in the agriculture and allied sector development and in the decision making of farmer's communities in different countries (Cash, 2001; Galloway and Mochrie, 2005; Opara, 2008 and Taragola and Van Lierde, 2010).

Information delivered through ICT can be timelier and can reach a greater number of farmers directly (Richardson, 1996). Access to ICTs could reduce transaction costs related to information searching and reduce knowledge and information asymmetries, particularly related to market price information (De Silva and Ratnadiwakara, 2008). Information, rewarded with success stories, can motivate human to adopt healthy livestock technologies. For instance, information on immunization, calf mortality, maternal mortality, sanitation, nutritional awareness and causes, prevention and treatment of disease can be disseminated far and wide via ICTs. Information helps the poor to avail of the opportunities and also reduce their vulnerability (Kiplang'at 1999). Farmers must be get information at the right time and place (De Silva and Ratnadiwakara, 2008).It is increasingly recognized that ICT is necessary for accessing required information and knowledge (Richardson 1997; Chapman et al., 2004; Anandajayasekeram et al., 2008; Mcnamara 2009; Aker 2010). The enhanced and smooth communication results in the overall development of the livestock sector of the country (Saravanan, 2010). 
The focus of this study was on the attitude of the farmers towards ICT based livestock service delivery system, their present attitude and level of knowledge on ICT based information delivery system, problem faced by the farmers to run-through this system, which will be very helpful for the improvement of the existing system as well as the development in advanced information delivery system in livestock sector of India.

\section{Materials and Methods}

An exploratory research design was conducted in the state of Rajasthan, North-East India on constraints percieved by livestock farmers in the use of ICTs. State was purposively selected through criterion sampling due to the Rajasthan is rich in livestock wealth and peoples of the state are using various ICT tools in their day to day life to adopt better life style. Further, Jaipur district was selected purposively on the basis of prospective rate of information acessibility, availability, usage, good informative network and livestock wealth status as compared to other districts of Rajasthan.

A total of 120 respondents who were using ICT tools were selected randomly from two tehsils of Jaipur district namely Sanganer and Shahpura. In the next stage of sampling, six villages were selected randomly from each selected tehsils. Chhitroli, Bhankrota khurd, Manohariya wala, Watika, Vidhani and Goner villages were selected from Sanganer tehsil and Chimanpura, Amarpura, Govindpura Dhabai, Markhi, Neejhar and Chhapra kalan were selected from Shahpura tehsil. Thus, total twelve villages were selected for the study.From each village, an exhaustive list of livestock farmers using ICT tools for livestock information was prepared. Out of these, 10 respondents were selected randomly. Thus, total 120 respondents were selected for the study. Different statistical tools like frequency, percentage, regression and correlation were used to draw the inferences.

\section{Attitude of livestock farmers towards ICTs}

Attitude is an organized predisposition to think, feel, perceive and behave towards a cognitive object. Attitude is the degree of positive or negative effect associated with some psychological object.

The Modified scale of Kumar and Ratnakar (2011) was used for measuring the attitude of livestock farmers towards ICT based livestock extension services. The scale consisted of 22 statements (twelve positive and ten negetive). The responses were recorded on a five point continuum representing strongly agree, agree, undecided, disagree, and strongly disagree with scores of 5,4,3,2, and1 for positive statements and vice-versa for negative statements, respectively. The maximum and minimum obtainable score was 110 and 22 respectively.

After getting the total attitude score of each respondent, they were classified into three groups as follows:

Less favourable - Less than (Mean - S.D.)

Favourable - Between (Mean \pm S.D.)

More favourable - More than (Mean + S.D.)

\section{Results and Discussion}

\section{Attitude of livestock farmers towards ICTs}

The attitude of the livestock farmers towards dissemination of livestock information through use of ICTs has been analysed in Table 1. A persual of this table reveals that a great majority of livestock farmers were in agreement with positive statements about information dissemination through ICTs like ICT based disease outbreak warning system facilitate farmers to take preventive measures 
(92.50\%), ICTs provide possible solutions to the present animal husbandry situation (86.67\%), ICT based extension services assist the farmer in planning and decision making aspects in animal husbandry $(85.83 \%)$, ICTs are potential tools to reach the needy farmers $(83.33 \%)$ and ICTs based extension services provide new opportunities to build a skilled and knowledgeable community (83.33\%).

Majority of them were also in agreement with the other positive statements like access to information centre at village level is boon to the farming community (76.67\%), phone-inlive with scientists gives first-hand information about queries $(74.17 \%)$, weather forecasting through ICTs assists farmers in timely decisions $(72.50 \%)$, farmers feedback is fast through ICTs than traditional methods (71.67\%), expert advice make the farmers enterprise/activities productive (69.17\%), farmers can get remunerative prices to their produce through ICT based market intelligence $(65.83 \%)$ and existing infrastructure of ICTs is not enough to meet the needs of the farming community (34.17\%).

Majority of the respondents had no opinion about the negative statements like ICTs cannot deliver personalized information (75.83\%), ICT based extension services avoid the personal extension contact (45.83\%) and ICTs cannot meet location specific needs of the livestock farmers $(43.33 \%)$.

Most of the livestock farmers were in disagreement with the other negetive statements like ICT based extension services are alternative to the present extension system (81.67\%), ICTs alone would solve the problems of farmers $(50.83 \%)$, ICT is a valuable tool, but it will never influence farmers own decision making (49.17\%) and only resourceful farmers can get the benefit of the ICTs $(45.83 \%)$. Equal per cent respondents $(45.83 \%)$ were in disagreement and strongly disagreement with the negative statement 'ICT services are a distant dream for resource poor farmers'.

The results presented in Table 2 suggests that majority of the livestock farmers (73.33\%) had favourable attitude towards dissemination of information through different ICT tools in livestock sector followed by 15.83 per cent with more favourable attitude and 10.83 per cent with less favourable attitude.

This finding indicates that livestock farmers of the study area were enthusiastic to perceive different ICTs tools to get their required information. This might be due to the fact that livestock farmers are getting timely and accurate livestock information and services based on their needs and desires. Livestock farmers are aware about the benefits of different ICT tools and their role in information dissemination towards livestock farming in near future

\section{Relationship between selected independent variables and attitude of livestock farmers towards ICTs}

The data presented in Table 3 indicates that age, family size, land holding, herd size, extension contact and social participation had positive and non-significant relationship with attitude of livestock farmers towards ICTs, while experience in livestock farming had negative and non-significant relationship. Education, mass media exposure and annual gross income had positive and significant relationship with attitude of livestock farmers towards ICTs.

Positive and significant association of education of livestock farmers with attitude towards ICTs may be attributed to the fact that educated people know the importance of ICTs and their positive impact on productivity of animals. 
Table.1 Distribution of livestock farmers on the basis of their attitude towards ICTs

\begin{tabular}{|c|c|c|c|c|c|c|c|c|c|c|c|}
\hline \multirow[t]{2}{*}{ S. No. } & \multirow[t]{2}{*}{ Statements } & \multicolumn{2}{|c|}{ SA } & \multicolumn{2}{|c|}{$\mathbf{A}$} & \multicolumn{2}{|c|}{ UD } & \multicolumn{2}{|c|}{ DA } & \multicolumn{2}{|c|}{ SDA } \\
\hline & & $f$ & $\%$ & $f$ & $\%$ & $f$ & $\%$ & $f$ & $\%$ & $f$ & $\%$ \\
\hline 1. & $\begin{array}{l}\text { ICTs provide possible solutions to the present animal } \\
\text { husbandry situation }\end{array}$ & 3 & 2.50 & 104 & 86.67 & 10 & 8.33 & 3 & 2.50 & 0 & 0.00 \\
\hline$*$ & $\begin{array}{l}\text { ICTs can not meet location specific needs of the livestock } \\
\text { farmers }\end{array}$ & 0 & 0.00 & 18 & 15.00 & 52 & 43.33 & 41 & 34.17 & 9 & 7.50 \\
\hline 3. & ICTs are potential tools to reach the needy farmers & 6 & 5.00 & 100 & 83.33 & 9 & 7.50 & 5 & 4.17 & 0 & 0.00 \\
\hline 4. & $\begin{array}{l}\text { Farmers feed back is fast through ICTs than traditional } \\
\text { methods }\end{array}$ & 33 & 27.50 & 86 & 71.67 & 1 & 0.83 & 0 & 0.00 & 0 & 0.00 \\
\hline$*$ & Illiteracy will not deter farmers in availing ICT services & 20 & 16.67 & 82 & 68.33 & 10 & 8.33 & 5 & 4.17 & 3 & 2.50 \\
\hline 6. & ICTs can not deliver personalized information & 0 & 0.00 & 10 & 8.33 & 91 & 75.83 & 19 & 15.83 & 0 & 0.00 \\
\hline 7. & $\begin{array}{l}\text { ICT based extension services assist the farmer in planning } \\
\text { and decision making aspects in animal husbandry }\end{array}$ & 6 & 5.00 & 103 & 85.83 & 5 & 4.17 & 6 & 5.00 & 0 & 0.00 \\
\hline$*$ & ICT services are a distant dream for resource poor farmers & 0 & 0.00 & 6 & 5.00 & 4 & 3.33 & 55 & 45.83 & 55 & 45.83 \\
\hline 9. & $\begin{array}{l}\text { Farmers can get remunerative prices to their produce through } \\
\text { ICT based market intelligence }\end{array}$ & 36 & 30.00 & 79 & 65.83 & 3 & 2.50 & 2 & 1.67 & 0 & 0.00 \\
\hline 10. & $\begin{array}{l}\text { Expert advice make the farmers enterprise/activities } \\
\text { productive }\end{array}$ & 33 & 27.50 & 83 & 69.17 & 2 & 1.67 & 1 & 0.83 & 1 & 0.83 \\
\hline 11. & $\begin{array}{l}\text { All kinds of information exchange are possible only through } \\
\text { ICTs }\end{array}$ & 3 & 2.50 & 2 & 1.67 & 12 & 10.00 & 84 & 70.00 & 19 & 15.84 \\
\hline 12. & $\begin{array}{l}\text { Existing infrastructure of ICTs is not enough to meet the } \\
\text { needs of the farming community }\end{array}$ & 13 & 10.83 & 53 & 44.17 & 41 & 34.17 & 8 & 6.67 & 5 & 4.17 \\
\hline 13. & Only resourceful farmers can get the benefit of the ICTs & 3 & 2.50 & 15 & 12.50 & 12 & 10.00 & 55 & 45.83 & 35 & 29.17 \\
\hline 14. & $\begin{array}{l}\text { Access to information centre at village level is boon to the } \\
\text { farming community }\end{array}$ & 13 & 10.83 & 92 & 76.67 & 11 & 9.17 & 3 & 2.50 & 1 & 0.83 \\
\hline 15. & $\begin{array}{l}\text { Phone-in-live with scientists gives first hand information } \\
\text { about queries }\end{array}$ & 29 & 24.17 & 89 & 74.17 & 0 & 0.00 & 1 & 0.83 & 1 & 0.83 \\
\hline 16. & ICTs alone would solve the problems of farmers & 1 & 0.83 & 22 & 18.33 & 15 & 12.50 & 61 & 50.83 & 21 & 17.50 \\
\hline 17. & $\begin{array}{l}\text { ICT based disease outbreak warning system facilitate farmers } \\
\text { to take preventive measures }\end{array}$ & 1 & 0.83 & 111 & 92.50 & 4 & 3.33 & 3 & 2.50 & 1 & 0.83 \\
\hline & $\begin{array}{l}\text { ICT based extension services avoid the personal extension } \\
\text { contact }\end{array}$ & 0 & 0.00 & 10 & 8.33 & 55 & 45.83 & 53 & 44.17 & 2 & 1.67 \\
\hline 19. & $\begin{array}{l}\text { ICTs based extension services provide new opportunities to } \\
\text { build a skilled and knowledgeable community }\end{array}$ & 10 & 8.33 & 100 & 83.33 & 8 & 6.67 & 2 & 1.67 & 0 & 0.00 \\
\hline 20. & $\begin{array}{l}\text { ICT is a valuable tool, but it will never influence farmers' } \\
\text { own decision making }\end{array}$ & 0 & 0.00 & 12 & 10.00 & 44 & 36.67 & 59 & 49.17 & 5 & 4.17 \\
\hline 21. & $\begin{array}{l}\text { Weather forecasting through ICTs assists farmers in timely } \\
\text { decisions }\end{array}$ & 32 & 26.67 & 87 & 72.50 & 1 & 0.83 & 0 & 0.00 & 0 & 0.00 \\
\hline 22. & $\begin{array}{l}\text { ICT based extension services are alternative to the present } \\
\text { extension system }\end{array}$ & 0 & 0.00 & 0 & 0.00 & 10 & 8.33 & 98 & 81.67 & 12 & 10.00 \\
\hline
\end{tabular}

SA: Strongly agree, A: Agree, UD: Undecided, DA: Disagree and SDA: Strongly disagree; * Negative Statements 
Table.2 Overall attitude of livestock farmers towards ICTs $(n=120)$

\begin{tabular}{|l|l|l|l|}
\hline S. NO. & \multicolumn{1}{|c|}{ A ttitude } & $f$ & $\%$ \\
\hline 1. & Less favourable (upto 71.43 score) & 19 & 15.83 \\
\hline 2. & Favourable (71.44 to 79 score) & 88 & 73.33 \\
\hline 3. & More favourable (Above 79 score) & 13 & 10.83 \\
\hline
\end{tabular}

Table.3 Pearson's correlation for attitude of livestock farmers towards ICTs with independent variables

\begin{tabular}{|l|l|c|}
\hline S. No. & \multicolumn{1}{|c|}{ Independent variables } & $\begin{array}{c}\text { Pearson's Correlation Cofficient } \\
\left(\mathbf{r}_{\mathbf{p}}\right)\end{array}$ \\
\hline $\mathbf{1 .}$ & Age & 0.101 \\
\hline 2. & Education & $0.186^{*}$ \\
\hline 3. & Family size & 0.122 \\
\hline $\mathbf{4 .}$ & Land holding & 0.023 \\
\hline $\mathbf{5 .}$ & Herd size & 0.014 \\
\hline 6. & Annual gross income & $0.242^{* *}$ \\
\hline 7. & Experience in livestock farming & -0.024 \\
\hline 8. & Extension contact & 0.014 \\
\hline 9. & Mass media exposure & $0.219^{*}$ \\
\hline 10. & Social participation & 0.093 \\
\hline
\end{tabular}

** Significant at 1 per cent level; * Significant at 5 per cent level

Table.4 Linear regression analysis for attitude of livestock farmers towards ICTs with independent variables

\begin{tabular}{|l|l|c|c|}
\hline S. No. & \multicolumn{1}{|c|}{ Independent variables } & $\boldsymbol{\beta}$ & t- value \\
\hline 1. & Age & .295 & $2.111^{*}$ \\
\hline 2. & Education & .237 & 1.984 \\
\hline 3. & Family size & .074 & .802 \\
\hline 4. & Land holding & -.142 & -1.396 \\
\hline 5. & Herd size & .059 & .620 \\
\hline 6. & Annual gross income & .130 & 1.199 \\
\hline 7. & Experience in livestock farming & -.134 & -.952 \\
\hline 8. & Extension contact & .039 & .404 \\
\hline 9. & Mass media exposure & .202 & $2.163 *$ \\
\hline 10. & Social participation & .124 & 1.349 \\
\hline
\end{tabular}

* Significant at 5 per cent level 
Further, positive and significant association of annual gross income and mass media exposure with attitude of livestock farmers towards ICTs clearly indicates that when the farmers have more annual gross income then their purchasing ability of ICTs increases and increased mass media exposure increases their awareness regarding the benefits of ICTs.

The data presented in Table 4 reveals that only two variables i.e. age and mass media exposure had positive and significant contribution on the attitude of livestock farmers towards ICTs. Land holding and experience in livestock farming had negative and non-significant contribution, whereas education, family size, herd size, annual gross income, extension contact and social participation had positive and non-significant contribution on the attitude of livestock farmers towards ICTs.

The results based on data analysis suggested that majority of the livestock farmers had favourable attitude towards dissemination of information through use of different ICT tools in livestock sector and some of them nearby sixteen per cent has more favourable attitude and nearby eleven per cent livestock farmers has less favourable attitude.

\section{References}

Aker JC. 2010. Dial 'A' for Agriculture: Using Information and Communication Technologies for Agricultural Extension in Developing Countries. Tuft University, Economics Department and Fletcher School, Medford MA02155.

Anandajayasekeram P, Puskur R, Workneh S and Hoekstra D. 2008. Concepts and practices in Agricultural extension in Developing countries: A source book. IFPRI (International Food Policy Research Institute), Washington, DC, USA, and ILRI (International Livestock Research Institute), Nairobi, Kenya. pp. 275.
Anonymous. 2005. Access to modern technology for farming, situation assessment survey of farmers, 59th Round, Report No. 499, National Sample Survey Organisation (NSSO), Ministry of Statistics and Programme Implementation, Government of India, New Delhi.

Borah M and Halim RA. 2014. Dynamics and Performance of Livestock and Poultry Sector in India: A Temporal Analysis. Journal of Academia and Industrial Research. 3 (1): 1-9.

Cash DW. 2001. In order to aid in diffusing useful and practical information: Agricultural extension and boundary organizations. Science Technology and Human Values. 26: 431-453.

Chapman R, Slaymaker T and Young J. 2004. Livelihoods Approaches to Information and Communication in Support of Rural Poverty Elimination and Food Security. Overseas Development Institute, UK Department of International Development and Food and Agricultural Organization.

De Silva H and Ratnadiwakara D. 2008. Using ICT to Reduce Transaction Costs in Agriculture Through Better Communication: A Case-Study from Sri Lanka. LIRNEasia.http://www.lirneasia. net/wpcontent/uploads/2008/11/transaction costs.pdf.

Elijah AO and Ogunlade I. 2006. Analysis of the uses of information and communication technology for gender empowerment and sustainable poverty alleviation in Nigeria. International Journal of Education and Development. 2 (3): 45-69.

Galloway L and Mochrie R. 2005. The use of ICT in rural firms: A policy orientated literature review. The Journal of Policy, Regulation and Strategy for Telecommunications. 7: 33-46.

Hazelman M and Flor AG. 2004. Regional prospects and initiatives for bridging the rural digital divide. AFITA/WCCA Joint Congress on Agriculture.

Kiplang'at J. 1999. An analysis of the opportunities for information technology in improving access, transfer and the use of agricultural information in the rural areas in 
Kenya. Library Management. 20 (2): 115127.

Kumar PG and Ratnakar R. 2011. A Scale to Measure Farmer's Attitude towards ICTbased Extension Services. Indian Research Journal of Extension Education. 11 (1): 109-112.

Maningas RV. 2006. Mainstreaming Farmers and Intermediaries Into Information and Communications Technology (ICT): A Strategy Towards Adopting ICT for Rural Development and Agricultural Extension. Computers in Agriculture and Natural Resources, 4th World Congress Conference, Proceedings of the 24-26 July 2006 (Orlando, Florida USA) Publication.

McNamara K. 2009. Improving Agricultural Productivity and Markets: The Role of Information and Communication Technologies. Agriculture and Rural Development Notes, Issue 47, April, The World Bank, Washington DC.

Mittal S and Kumar P. 2000. Literacy, technology adoption, factor demand and productivity: An economic analysis. Indian Journal of Agricultural Economics. 55 (3): 490-499.

NSSO. 2005. Situation assessment survey of farmers: Access to modern technology for farming, 59th round (January-December 2003). Report No. 499(59/33/2), Ministry of Statistics and Programme Implementation, Government of India. New Delhi.

Opara UN. 2008. Agricultural information sources used by farmers in Imo State, Nigeria. Information Development. 24 (4): 289-295.

Ravikumar RK and Mahesh C. 2006. Extension educational efforts by State Department of Animal Husbandry (SDAH), Tamil Nadu: SWOT analysis. Livestock Research for Rural Development, 18. Retrieved from http://www.lrrd.org/lrrd18/9/ ravi18126.html.

Richardson D. 1996. The Internet and rural development: recommendations for strategy and activity-final report. Rome: Sustainable Development, Department of the Food and Agriculture Organization of the United Nations. http://www.fao.org/sd-dimensions.

Richardson D. 1997. The Internet and Rural and Agricultural Development: An Integrated Approach. Rome: FAO.

Saravanan R. 2010. ICTs for Agricultural Extension: Global Experiments, Innovations and Experiences. New India Publishing Agency, New Delhi.

Saravanan R. 2011. A Report on Tribal Farmers Personal and Socio-Economic Information, Communication Pattern and Information Needs Assessment. In: e-Agrikiosk Pub. No. 1.

Sasidhar PVK and Sharma VP. 2006. Cyber livestock outreach services in India: a model framework. Livestock Research for Rural Development. 18. http://www.lrrd.org/ lrrd18/1/sasi18002.html.

Taragola NM and Van Lierde DF. 2010. Factors affecting the internet behaviour of horticultural growers in Flanders, Belgium. Computers and Electronics in Agriculture. 70: 369-379.

\section{How to cite this article:}

Sunil Rajoria, Sanjay Kumar Rewani, Virendra Singh, Manisha Singodia, Brijesh Nanda and Harshita Bhumra. 2018. Attitude of Livestock Farmers towards the ICT based Livestock Extension Services in Jaipur District of Rajasthan, India. Int.J.Curr.Microbiol.App.Sci. 7(02): 1014-1021. doi: https://doi.org/10.20546/ijcmas.2018.702.125 